\title{
A PRÁTICA DOCENTE NOS FILMES FRANCESES: ENTRE OS MUROS DA ESCOLA E SER E TER
}

\author{
Cristina Francisca de Carvalho Porto * \\ Douglas Altamiro Consolo **
}

\begin{abstract}
Resumo: O presente artigo tem como objetivo tecer algumas considerações sobre a prática docente em dois filmes franceses que abordam a temática do ambiente escolar: Entre os muros da escola (2008), de Laurent Cantet; e, Ser e Ter (2002), de Nicolas Philibert. Para tal estudo adotamos como base teórica os textos de Paulo Freire (2001) e Philippe Perrenoud (2000), e a partir destes textos fazemos algumas reflexões acerca da prática docente, salientando os pontos positivos e negativos das práticas apresentadas nos filmes citados. Como resultado, esperamos, a partir dos questionamentos elencados nos filmes, salientar a(s) competência(s) necessárias para uma atuação docente eficaz do professor em sala de aula.
\end{abstract}

Palavras-chave: Prática docente. Formação de professores. Cinema francês.

Abstract: This article aims at discussing teaching practices depicted in two well-known French films dealing with school environment: Entre les Murs (2008), by Laurent Cantet, and Etre et Avoir (2002), by Nicolas Philibert. The theoretical bases for the study include the texts of Paulo Freire (2001) and Philippe Perrenoud (2000), and based on these texts teaching practices are considered, highlighting the positive and the negative aspects of the practices shown in the aforementioned films. As a result, from the critical issues indicated in the films, we expect to highlight the competences necessary for teachers to accomplish their pedagogical tasks more efficiently.

Keywords: Teaching practice. Teacher education. French cinema.

\section{Introdução}

Quando propomos aos professores brasileiros leituras acerca das competências docentes apresentadas na sua maioria por autores de língua francesa, o primeiro questionamento desses docentes é: Será que a teoria apresentada por autores de países considerados de primeiro mundo podem trazer algum benefício para nossa realidade? Assim, para mostrar a esses professores que sim, podemos nos beneficiar destas teorias, visto que a realidade de outros países é próxima da nossa. Optamos por fazer um estudo da prática docente em dois filmes franceses, cujo tema mostra bem os conflitos e problemas enfrentados em sala de aula, e que se assemelha ao que enfrentamos no Brasil. Os filmes são Entre os muros da escola e Ser e Ter. Percebemos que, assim como no Brasil, na França também existem exemplos bons e ruins no que concerne à prática docente, e estes dois filmes são exemplos desta realidade.

Como base teórica principal para nossas reflexões, remetemos-nos a dois estudiosos de grande relevância para os estudos acerca dos saberes docentes. Apresentamos, a seguir, uma breve explanação do pensamento, desses teóricos, presente nas obras que serviram de referência para esta pesquisa.

Paulo Freire (2001) apresenta reflexões sobre os saberes necessários à prática educativa-crítica, fundamentada na ética e alicerçada na pesquisa. Segundo o autor, sem

\footnotetext{
* Pesquisadora do GAMPLE - Grupo de Pesquisa junto ao Departamento de Letras Modernas do Ibilce/Unesp. Coordenadora do CEL da EE "Monsenhor Gonçalves". Rua Presciliano Pinto, 940, Boa Vista, Cep: 15025-100, São José do Rio Preto - SP. Telefone: (17) 30115657. Endereço eletrônico: crisfcporto@ gmail.com

** Prof. Adjunto de Língua Inglesa do Departamento de Letras Modernas do Ibilce/Unesp. Rua Cristovão Colombo, 2265, Jardim Nazareth, Cep: 15054-000, São José do Rio Preto - SP. Telefone: (17) 32212505. Endereço eletrônico: dconsolo@ terra.com.br / dconsolo@ibilce.unesp.br
} 
autonomia não há prática de ensino e nem aprendizagem. A competência técnico-científica deve ser inerente ao professor e o discurso engajado sozinho não resolve, se a ação pedagógica não for aberta às mudanças. Para Freire, a prática pedagógica docente deve estar inserida na dimensão social da formação humana e ele adverte que é preciso uma postura vigilante contra todas as práticas de desumanização. Para Freire, ensinar é muito mais do que apenas transferir conteúdos, como muitos pensavam em décadas passadas, é criar possibilidades para a produção e construção do conhecimento e que docente e discente são sujeitos dos acontecimentos. Ele reforça a ideia de uma prática docente democrática, a qual considera o aprendiz como sujeito do processo de aprendizagem. Segundo Freire (2001), o professor deve gostar do seu trabalho, querer bem aos seus alunos, ter afetividade para com todos, respeitar as pessoas como elas são e suas culturas, entre outras características.

Segundo Perrenoud (2000), outro teórico que alicerça nossas reflexões, o professor deve ter habilidade de colocar o saber em prática e ter atitude positiva frente ao desenvolvimento do seu trabalho e à sua realização com eficiência e eficácia. Assim, a partir dessa ideia, ele organizou dez grandes famílias de competências docentes, elencadas a seguir:

1) organizar e dirigir situações de aprendizagem;

2) administrar a progressão das aprendizagens;

3) conceber e fazer evoluírem os dispositivos de diferenciação;

4) envolver os alunos em suas aprendizagens e em seu trabalho;

5) trabalhar em equipe;

6) participar da administração da escola;

7) informar e envolver os pais;

8) utilizar novas tecnologias;

9) enfrentar os deveres e os dilemas éticos da profissão; e,

10) administrar sua própria formação contínua.

Todas estas competências, apresentadas por Perrenoud, muitas vezes são vistas como ideologias, que não se encaixam na realidade brasileira devido à falta de políticas que possibilitem a construção de tais competências. Membros da comunidade escolar (professores, coordenadores e diretores) concordam que são competências necessárias e importantes, mas reconhecem que muitas vezes não é possível ao professor alcançar algumas delas devido à falta de possibilidades, falta de estrutura nas escolas, falta de recursos. Porém, existem algumas ilhas de excelência, seja no setor público ou privado, em que o professor pode contar com um apoio que permite chegar-se a um bom nível em todas estas competências. O professor encontra, nesses casos, recursos tecnológicos, cursos de formação continuada, além de acompanhamento adequado por parte do corpo gestor.

Tendo apresentado, brevemente, princípios da competência docente que apóiam este estudo, tratamos, a seguir, dos filmes utilizados em nossa discussão, na expectativa de traçarmos um paralelo entre fatos mostrados nos filmes e fatos da realidade escolar. Objetivamos, com esta discussão, realçar o entendimento sobre as competências docentes e contribuir para um ensino mais eficiente.

\section{Entre os muros da escola: um espaço conflitante}

Começamos nossas reflexões com o filme francês Entre os muros da escola (Entre les murs), de Laurent Cantet, indicado ao Oscar de melhor filme estrangeiro e vencedor da Palma de Ouro no Festival de Cannes em 2008. O filme mostra o ambiente escolar em que François e seus colegas professores preparam o novo ano letivo em uma difícil escola da 
periferia parisiense. Munidos das melhores intenções, eles se apóiam mutuamente para manter vivo o estímulo de dar a melhor educação a seus aprendizes. Na sala de aula são retratados os choques entre as diferentes culturas presentes naquele espaço.

O filme conta o cotidiano de uma sala de aula e seus arredores durante um ano letivo. Logo no início há a apresentação dos novos professores, alguns conselhos dos que estão para se aposentar, a coordenação, as reuniões, as leituras, etc. A história se passa em uma escola especial, formada por filhos de imigrantes e franceses pobres, a classe é multiétnica, com africanos, asiáticos, europeus e latinos.

O professor, personagem principal do filme, é representado por François Bégaudeau, professor de Literatura e romancista que escreveu o livro de mesmo título do filme. O mérito da história está justamente na abertura feita por Bégaudeau, que propõe expor suas visões da sala de aula e suas reações diante dela do modo mais humano possível.

O filme se tornou um exemplo de quadro universal escolar por retratar conflitos, dificuldades e dilemas comuns em escolas de todo o mundo. Sua narrativa apresenta diferentes identidades e comunidades contemporâneas que se reproduzem nas escolas e os dramas que daí surgem são idênticos ao que acontecem também aqui no Brasil ou em qualquer outro país.

Toda a história gira em torno da aula de língua francesa, o professor François com seus alunos que entram em conflito com ele por qualquer motivo. Diante de tantos atritos tornam-se evidente os problemas de convivência em sala de aula e na relação professoraprendiz, obstáculos que podem ser facilmente comparados com a realidade brasileira. E, neste caso, a questão não é somente quanto à dificuldade de se ensinar, mas sobretudo na construção de sentido do que é ensinado, para que serve aquilo tudo. Questionamento este que tem se mostrado muito presente no panorama educacional, configurando o que se conhece pela crise do ensino e suas derivações, má qualidade, fracasso escolar, gestão administrativa deficiente, pouco investimento e falta de estrutura.

A falta de sentido do que é ensinado em sala de aula, a descontextualização dos conteúdos, é uma questão que preocupa há muito tempo e Morin (2003) chama isso de "Pertinência no conhecimento". Conforme Morin,

Para articular e organizar os conhecimentos e assim reconhecer e conhecer os problemas do mundo, é necessária a reforma do pensamento. Entretanto, esta reforma é paradigmática e, não, programática: é a questão fundamental da educação, já que se refere à nossa aptidão para organizar o conhecimento. A esse problema universal confronta-se a educação do futuro, pois existe inadequação cada vez mais ampla, profunda e grave entre, de um lado, os saberes desunidos, divididos, compartimentados e, de outro, as realidades ou problemas cada vez mais multidisciplinares, transversais, multidimensionais, transnacionais, globais e planetários.

Nessa inadequação tornam-se invisíveis:

- $\mathrm{O}$ contexto

- O global

- O multidimensional

- O complexo

Para que o conhecimento seja pertinente, a educação deverá torná-los evidentes. (MORIN, 2003, p. 35-36).

Vemos que a ligação dos conhecimentos se faz indispensável em nossa época, é um desafio das instituições escolares fazer esta ligação, mas o ensino continua dividido e fragmentado. Isso fica bem evidente na sala do professor François em que percebemos que além de não fazer essa contextualização, ele ignora totalmente a diversidade cultural existente em sua sala, a tal ponto que alguns alunos chegam a questioná-lo, dizendo que o professor só 
usa como exemplos nomes norte-americanos como Bob e que nunca usa nomes árabes, africanos ou asiáticos, nações de origem dos alunos da sala. E este questionamento é ignorado pelo professor, que não justifica nada aos aprendizes.

Por serem imigrantes de nações diversas temos a impressão que os alunos levam para a escola os problemas políticos de suas culturas. Assim alguns elementos que chamam a atenção no filme logo de início são: a presença desses grupos com interesses conflitantes que se expressam também na escola, dentro da sala de aula; as relações de poder que se estabelecem demonstrando a dominação do homem sobre o homem.

Nesse sentido Paulo Freire (2001, p. 30) propõe que "ensinar exige respeito aos saberes dos educandos", ele une a importância de chamar a atenção para a contextualização do que é ensinado como também a valorização do conhecimento e das histórias dos aprendizes.

Por isso mesmo pensar certo coloca ao professor ou, mais amplamente, à escola, o dever de não só respeitar os saberes com que os educandos, sobretudo os das classes populares, chegam a ela - saberes socialmente construídos na prática comunitária - mas também, como há mais de trinta anos venho sugerindo, discutir com os alunos a razão de ser de alguns desse saberes em relação com o ensino dos conteúdos. Por que não aproveitar a experiência que têm os alunos de viver em áreas da cidade descuidadas pelo poder público para discutir, [...]. Por que não estabelecer uma "intimidade" entre os saberes curriculares fundamentais aos alunos e a experiência social que eles têm como indivíduos? Por que não discutir as implicações políticas e ideológicas de um tal descaso dos dominantes pelas áreas pobres da cidade? (FREIRE, 2001, p. 30).

Por certo o professor François não concordaria com nosso autor, já que ele praticamente não aproveita em nada o conhecimento prévio de seus aprendizes, não explora a história individual destes e muito menos a cultura diversa de cada um. E, talvez essa falta de interesse seja o principal fator a causar o clima conflitante que vive sua sala de aula. Não há discussão amigável nessa sala, pois o que percebemos é que geralmente o docente exige silêncio para que somente ele possa falar, há um excesso de rigidez que distancia os alunos do professor e cria um clima tenso na sala.

No processo de aprendizagem um dos principais elementos que auxiliam no desenvolvimento do aprendiz é a interação, isto é, o sujeito se constitui em uma relação com o outro sujeito. O sujeito é construído por uma história individual, traz consigo anseios e desejos, ele produz história e por meio dela se transforma, nesta sala de aula específica do filme, com uma diversidade cultural muito rica, o professor não soube aproveitar esta riqueza, ele praticamente ignora essas diferenças entre os aprendizes, não procurando em nenhum momento trabalhar positivamente com isto. Não que ele seja totalmente alheio aos alunos e seus problemas, sentimos no decorrer do filme certo envolvimento do professor, mas que nunca ultrapassa as intenções. Na verdade, ele não se engaja realmente com a aprendizagem de seus alunos e muito menos com suas problemáticas.

O professor que desrespeita a curiosidade do educando, o seu gosto estético, a sua inquietude, a sua linguagem, mais precisamente, a sua sintaxe e a sua prosódia; o professor que ironiza o aluno, que o minimiza, que manda que "ele se ponha em seu lugar" ao mais tênue sinal de sua rebeldia legítima, tanto quanto o professor que se exime do cumprimento de seu dever de propor limites à liberdade do aluno, que se furta ao dever de ensinar, de estar respeitosamente presente à experiência formadora do educando, transgride os princípios fundamentais éticos de nossa existência. É neste sentido que o 
professor autoritário, que por isso mesmo afoga a liberdade do educando, amesquinhando o seu direito de estar sendo curioso e inquieto, tanto quanto o professor licencioso, rompe com a radicalidade do ser humano - a de sua inconclusão assumida em que se enraíza a eticidade. É neste sentido também que a dialogicidade verdadeira, em que os sujeitos dialógicos aprendem e crescem na diferença, sobretudo, no respeito a ela, é a forma de estar sendo coerentemente exigida por seres que, inacabados, assumindo-se como tais, se tornam radicalmente éticos. (FREIRE, 2001, p. 59-60).

Seguindo o pensamento freiriano, o professor François teria desrespeitado todos os direitos de seus aprendizes, não apenas por ignorar suas diferenças, mas também o gosto específico de cada um, ele abusou de sua autoridade utilizando a disciplina como um instrumento de dominação e de controle destinado a suprimir ou domesticar os comportamentos divergentes. Um regime disciplinar em que os indivíduos são diferenciados em relação uns aos outros e medidos quantitativamente.

Digamos que falta ao professor do filme a prática do bom-senso. Por algum motivo que não fica evidente no filme, não há este bom-senso por parte do docente e também não há um esforço de sua parte que sinalize uma possível mudança neste sentido.

É o meu bom-senso que me adverte de que exercer a minha autoridade de professor na classe, tomando decisões, orientando atividades, estabelecendo tarefas, cobrando a produção individual e coletiva do grupo não é sinal de autoritarismo de minha parte. É a minha autoridade cumprindo o seu dever. Não resolvemos bem, ainda, entre nós, a tensão que a contradição autoridade-liberdade nos coloca e confundimos quase sempre autoridade com autoritarismo, licença com liberdade.

Meu bom-senso me diz.

Saber que devo respeito à autonomia, à dignidade e à identidade do educando e, na prática, procurar a coerência com este saber, me leva inapelavelmente à criação de algumas virtudes ou qualidades sem as quais aquele saber vira inautêntico, palavreado vazio e inoperante. De nada serve, a não ser para irritar o educando e desmoralizar o discurso hipócrita do educador, falar em democracia e liberdade mas impor ao educando a vontade arrogante do mestre. (FREIRE, 2001, p. 61-62).

É nítido que falta este bom-senso ao professor François, mas não podemos crucificálo por essa limitação, atribuindo somente a ele a culpa de todos os problemas de sua sala, pois se estes problemas ocorrem é porque também não há nenhuma orientação para seu trabalho, ele não procura e nem é procurado no sentido de receber um apoio pedagógico. Percebemos, neste filme, que a escola tem uma gestão totalmente apática, que não dá suporte aos professores e a consequência disto se reflete nas salas de aula.

O professor tenta, à sua maneira, resolver os conflitos em sala, o que além de não dar certo ainda lhe cria problemas maiores. Quando chama a atenção de um aluno, por exemplo, o faz de forma autoritária e humilhando-o, como o fez com Souleymane, que não aceita ser humilhado e resolve enfrentar o professor, então se inicia uma discussão na sala e assim instaura-se o caos. O professor, sem ao menos ouvi-lo, sem ter em nenhum momento conversado com o jovem sobre as razões de ele não ter participado da atividade, passa o problema para a direção da escola, e este ato resulta na expulsão do adolescente.

O professor procura resolver as situações difíceis mas sem conseguir estruturá-las de fato, ele se posiciona diante do aprendiz de igual para igual, o que acaba levando a uma discussão. O seu posicionamento tem uma repercussão muito negativa, pois o professor deveria servir de exemplo, procurando solucionar o problema. 
O drama do filme se constrói ao redor do personagem Souleymane. Um dia esse aluno trata o professor com agressividade e sem querer machuca uma de suas colegas ao se retirar da sala. Tudo começa após uma discussão sobre o fato de o professor ter ou não direito de tratar as alunas de "vagabundas" em função do comportamento delas no conselho de classe. O que desencadeou este incidente foi a descoberta por Souleymane de que seu professor havia dito no conselho de classe que ele era "limitado".

Toda a confusão que culminou na expulsão do jovem na verdade iniciou-se fora da sala de aula, durante o conselho de classe. Duas alunas participavam desta reunião, elas não receberam nenhuma instrução para ocuparem este cargo de representantes da sala, o que já é um agravante. Durante a reunião os professores, ao comentarem sobre o desempenho dos alunos, se referiram a Souleymane como "limitado" e o professor François reforça esse comentário dizendo que não exige muito dele por saber desta limitação. As duas alunas repassam essa informação para o colega de classe, que naturalmente se revolta, alterando seu comportamento em sala de aula. O professor, ao tomar conhecimento do fato, diz a essas alunas que elas parecem "vagabundas". Diante disso, a turma toda toma partido das alunas, dizendo que o professor não tinha direito de tratá-las assim. Essa discussão extrapola a sala de aula e continua no pátio da escola, com todos os alunos ao redor do professor, tirando satisfação do fato.

Isto mostra não apenas falta de ética do professor como também falta de preparo didático deste, que não soube dialogar com sua turma de uma maneira pacificadora, para que se encontrasse uma solução menos dramática para o posicionamento dos aprendizes.

O filme permite se questionar sobre qual seria a boa distância em relação aos alunos; qual o nível de linguagem que devemos utilizar com eles. O principal dilema neste filme se deu justamente por extrapolar este limite, o professor passou a fronteira do respeito ao tentar se aproximar demais do mundo dos adolescentes, pois, ao se colocar no mesmo nível deles, ele perde sua autoridade.

Vemos aqui o caráter ilusório e perigoso de igualdade instaurada entre o professor e seus aprendizes, por mais que se queira ser amigo da turma é sempre necessário saber onde parar, não perdendo o limite entre educador e alunos, certa autoridade, baseada em um respeito mútuo é sempre necessária para que a aprendizagem continue acontecendo.

É claro que há aspectos positivos nesse professor, percebemos nele, certo desejo de ensinar e a consciência de suas fraquezas pedagógicas, mas pára aí, ele não se engaja realmente com o processo.

Estamos diante de um professor com boas intenções, gosta de seus alunos, até defende-os quando necessário. Ele procura fazer a ponte entre a cultura jovem e os saberes escolares, mas ao se aproximar demais ele perdeu o limite. Há no filme um único momento em que o professor permite aos jovens se expressarem da forma que cada um achar melhor, quando ele faz uma atividade na sala de informática em que cada aluno deve fazer uma apresentação daquilo que mais gostar. Esta é a única atividade em que há interação e liberdade e percebemos que neste momento não há conflitos, não há desavenças. Talvez se ele seguisse mais este estilo de ensino não teria tido os problemas que teve.

Isto nos mostra a fragilidade da confiança construída somente a partir da afetividade, sem um "contrato intelectual", sem um engajamento recíproco, nem professor, nem aprendizes, nem gestores, nem pais, se mostram engajados com o processo de ensino. A escola é ausente a partir do momento em que recusa a educação de um único aluno. Recusa por que, ao expulsar aquele que na verdade foi vítima da falta de preparo de seus professores, eles erraram, pois não deram oportunidade de defesa e nem ao menos tentaram entender os problemas que levaram à limitação deste aprendiz. Nunca houve um interesse em recuperar este jovem, o que fizeram foi apenas livrar-se do problema, quando na verdade seu papel era tentar recuperá-lo. 
A solidariedade e o senso de responsabilidade são estreitamente dependentes do sentimento de justiça. Não se pode ser solidário com aqueles que se julga infinitamente privilegiados e mobilizar-se em seu favor quando sua sorte muda. Ainda aqui, os princípios de formação disputam com as lógicas de ação. Até um professor indiferente ao desenvolvimento do sentimento de justiça fora da escola não pode ignorá-lo porque seu trabalho cotidiano depende disto. Quando se pergunta aos alunos do mundo inteiro o que eles esperam dos professores, eles dizem grosso modo: um certo calor e senso de justiça. (PERRENOUD, 2000, p. 153).

Notamos que não houve senso de justiça no caso de Souleymane, que foi abandonado por aquele que deveria estar ao seu lado, tentando entende-lo, o seu professor. François com certeza deveria ter se posicionado com mais firmeza no conselho de classe que decidiu sobre a expulsão do aluno, ele ficou calado e apático, mesmo sabendo que tinha culpa pela atitude explosiva do menino.

Se procurarmos neste professor as dez competências sugeridas por Perrenoud (2000), veremos que muito pouco é visto neste sentido. Como podemos confirmar em nossa reflexão nos tópicos a seguir.

Organizar e dirigir situações de aprendizagem: neste tópico o autor sugere que se trabalhe a partir das representações dos aprendizes, dos erros e obstáculos à aprendizagem, que se envolvam os alunos em atividades de pesquisa, e o que vimos foi praticamente nenhuma ação para isso, pelo contrário, houve uma fuga deste tipo de prática.

Administrar a progressão das aprendizagens, ou seja, conceber e administrar situações-problemas ajustadas ao nível e às possibilidades dos alunos, observar e avalia-los em situações de aprendizagem, de acordo com uma abordagem formativa, fazer balanços periódicos de competências e tomar decisões de progressão: no filme em questão, esta prática foi contrária, quando o professor se vê diante de um aprendiz com graves problemas de aprendizagem, ele simplesmente o abandona, como ele mesmo disse - "não se exige nada dele já que ele não será capaz de fazê-lo", ou seja, nenhuma decisão sensata foi tomada para que houvesse alguma progressão na aprendizagem desse aprendiz.

Conceber e fazer evoluir os dispositivos de diferenciação, administrando a heterogeneidade no âmbito da turma, ampliar a gestão de classe para um espaço mais vasto, fornecer apoio integrado, trabalhar com alunos portadores de grandes dificuldades, desenvolver a cooperação entre os aprendizes e formas simples de ensino mútuo. Tais ações não apenas foram deixadas de lado na prática deste professor como também não foram estimuladas a serem trabalhadas pelos aprendizes e o único momento em que vemos uma cooperação parte da turma, quando estes resolvem se unir contra o professor para defenderem suas colegas.

Envolver os alunos em suas aprendizagens e em seu trabalho, procurando suscitar neles o desejo pelo aprender, explicitar a relação com o saber, o sentido do trabalho escolar e desenvolver neles a capacidade de auto-avaliação, instituir um conselho de alunos e negociar com eles diversos tipos de regras e de contratos: como já vimos anteriormente, não há esta ligação entre o que se aprende e a vida dos alunos, muito menos há uma busca em envolvê-los na aprendizagem; também não houve negociação e foi justamente isto que ocasionou o drama principal do filme, a falta de regras, de conversar com as alunas sobre o seu papel no conselho de classe.

Trabalhar em equipe, enfrentar e analisar em conjunto situações complexas, práticas e problemas profissionais, administrar crises ou conflitos interpessoais: no filme, François além de não procurar promover o trabalho em equipe na sua sala de aula, também não o fazia consigo mesmo, visto que nas reuniões com seus pares ele pouco conversava, pouco se 
manifestava, no momento de crise tentou primeiro resolver o problema sozinho e como não conseguiu passou o caso para a direção, não dividindo com eles a procura por uma solução menos dramática.

Participar e envolver os pais é talvez um dos aspectos menos presente neste filme, os pais só aparecem quando chamados pela direção em decorrência de algum problema com o filho. Como ocorreu com Souleymane, cuja mãe, que não falava francês, teve que ir até a diretoria da escola ouvir sobre o problema do filho e o próprio aluno serviu como intérprete da mãe, que pouco entendeu da situação.

Quanto à utilização de novas tecnologias, há nesse sentido uma tentativa por parte do professor. Ele leva seus alunos para desenvolverem uma atividade no laboratório de informática e ponto, a atividade fica naquele momento, não mais é retomada em nenhum outro trecho do filme.

Enfrentar os deveres e os dilemas éticos da profissão e administrar a própria formação contínua, estas duas últimas competências propostas por Perrenoud tratamos em conjunto, pois no filme, a nosso ver elas não existem e estão diretamente ligadas. Se o professor não administra sua formação contínua também não terá subsídios para enfrentar estes dilemas da profissão e muito menos cumprir adequadamente com seus deveres de educador, ainda que este tenha uma boa intenção, como nos parece ter o professor François. Nesse sentido, segundo Perrenoud,

As boas intenções não bastam, nem uma hábil mistura de convicção e realismo. É preciso que se criem situações que facilitem verdadeiras aprendizagens, tomadas de consciência, construção de valores, de uma identidade moral e cívica. Ao se começar esse trabalho didático, percebe-se que uma educação para a cidadania não pode ser limitada a uma grade horária e que "a formação do cidadão se esconde, na escola, no coração da construção dos saberes". Eu acrescentaria que ela também passa pelo conjunto do currículo, explicita ou ocultamente. Como prevenir a violência na sociedade, se ela é tolerada no recinto da escola? Como transmitir o gosto pela justiça, se ela não é praticada em aula? Como incutir o respeito, sem encarnar este valor no dia-a-dia? Diz-se, às vezes, que "ensina-se o que se é". No domínio que nos ocupa, isso é ainda mais verdadeiro. $\mathrm{O}$ "faça o que eu digo, mas não o que eu faço" não tem chance alguma de mudar as atitudes e as representações dos alunos. (PERRENOUD, 2000, p. 142-143).

Os aspectos supracitados ficam bem claros nesse filme, em que os aprendizes são a imagem de seu professor e, ao mesmo tempo, são também imagem de suas famílias. Se a sociedade não cumpre seu papel de educar seus filhos, também a escola não faz e, assim esses adolescentes continuam a repetir os exemplos de seus familiares e, principalmente, de seus professores. Se o professor os tratou com grosseria e não teve o senso de justiça, por que eles, alunos, o teriam?

Podem-se considerar as cinco competências específicas fixadas pelo referencial aqui adotado como outros tantos recursos de uma educação coerente com a cidadania:

- Prevenir a violência na escola e fora dela.

- Lutar contra os preconceitos e as discriminações sexuais, étnicas e sociais.

- Participar da criação de regras de vida comum referentes à disciplina na escola, às sanções e à apreciação da conduta.

- Analisar a relação pedagógica, a autoridade e a comunicação em aula.

- Desenvolver o senso de responsabilidade, a solidariedade e o sentimento de justiça. 
Os professores que desenvolvem tais competências trabalham não só para o futuro, mas para o presente. Criam condições de um trabalho escolar fecundo no conjunto das disciplinas e dos ciclos de estudos. Não se trata apenas de incutir um modelo para que os alunos "o levem pela vida afora", mas de colocá-lo em prática "aqui e agora" para torná-lo confiável e, simultaneamente, para que dele sejam extraídos benefícios imediatos. (PERRENOUD, 2000, p. 143).

Se esta proposta de Perrenoud fosse seguida pela escola que vimos no filme, provavelmente sua realidade seria outra que não esta apresentada. $\mathrm{O}$ que mais faltou nessa escola foi sem dúvida a comunicação, senso de responsabilidade, de solidariedade, sentimento de justiça, por parte de todos, alunos e professores, e por que não dizer, da comunidade em geral.

Devido a todos esses problemas, temos no filme, Entre os muros da escola, a exposição de uma sala de aula que se mostra um terreno extremamente sensível, no qual se instauram vários medos: os pais sentem medo que seus filhos sejam vítimas de bárbaros; há a inquietação diante de uma juventude que acreditamos não conseguir dominar; e, principalmente o enfraquecimento de uma sociedade incapaz de afirmar seus princípios e valores, uma problemática cuja esperança da solução parece estar longe de existir.

Entre os muros da escola foi projetado inicialmente para ser um filme, mas tomou ares de documentário, talvez por praticamente não ter atores profissionais, visto que todos os participantes eram alunos da própria escola, que nunca atuaram, assim como o professor, que é escritor e aceitou representar esse papel no filme. Ao contrário de Ser e Ter, que é um documentário e mais parece um filme. Isto ocorreu talvez porque aqui temos ultrapassado o espaço da sala de aula, participamos da vida particular das crianças, a história contada tem início, meio e fim, um encadeamento narrativo que não se espera em um documentário.

\section{Ser e Ter: professor e aprendizes em uma narrativa única}

Neste filme percebemos a intenção do autor em filmar histórias reais entre pessoas únicas e em um lugar único também. Histórias singulares como o laço tecido pelo professor com cada um de seus aprendizes. Histórias de amor, humanidade que nos faz rir, chorar e nos emocionarmos.

O professor Lopez é bem tradicional em sua prática, o que não importa ao diretor, visto que a proposta inicial não é a pedagogia em si, mas o processo de como aprendemos a ler, escrever e a construir nosso raciocínio.

Temos uma sala de aula multiseriada, de uma escola do interior da França, no Puyde-Dôme, com aprendizes de diferentes idades. É uma escola rural que não comporta um número suficiente de alunos para formar uma sala para cada nível.

$O$ que se percebe é uma pedagogia mais da pergunta-resposta do que do questionamento, na sala o professor é a personificação da lei, o que não implica todavia em autoritarismo.

É um professor que demonstra amor por sua profissão e uma atenção bem diferenciada para cada um de seus aprendizes. E é nesta história de amor que está o grande mérito do filme. Lopez ama sua profissão, desde o início do filme sentimos sua felicidade de estar na classe e de ajudar seus alunos em suas dificuldades de aprendizagem. Mas chama a atenção o clima de exigência e respeito ali presentes. Todas as atividades sempre são desenvolvidas no silêncio e com calma até o final.

Lopez oferece às crianças um ensino tradicional, firme, mas que sabe ser presente diante dos problemas de cada um. O professor consegue criar um clima agradável e caloroso, 
que facilita seu diálogo com os alunos. Sua autoridade natural se apaga diante das palavras carinhosas das crianças ou de uma brincadeira com os menores.

Ao contrário do filme anteriormente analisado, em Ser e Ter o trabalho em equipe é muito valorizado, os alunos só trabalham em grupos, há muita cooperação entre eles, geralmente os maiores ajudam os menores, este clima de cooperação é incentivado o tempo todo pelo professor.

Não vamos repetir aqui todas as competências, mas apenas ressaltar o que mais se destaca neste filme: o engajamento do professor. Fica evidente que tudo acontece de maneira agradável devido a sua presença marcante e por seu amor à profissão, sua dedicação.

Vimos no filme anterior que o principal drama se deu pela falta de comunicação e pela forma drástica com que foi tratada a falta de disciplina, em Ser e ter ao contrário, o professor, quando percebe um problema de indisciplina na sala de aula, chama os alunos envolvidos separadamente e escuta cada versão do fato; em seguida expõe o que ele acha ser correto e propõe um acordo de amizade para ambos. Assim, está resolvido o problema, sem chamar ninguém que não participou do acontecimento, usa-se apenas o diálogo. O professor mostra uma autonomia na resolução do problema e, principalmente, um grande senso de justiça, ainda que isso seja próprio de sua personalidade. Segundo Perrenoud,

Cada pessoa aborda um conflito com sua própria identidade, que depende de seu desenvolvimento pessoal, ou seja, de sua história pessoal e de sua formação. Os adultos jamais pararam de oscilar entre a submissão e a revolta contra os poderes, jamais estão certos de ter o direito de serem diferentes sem serem desviados. O conflito salienta a lateridade e evoca a autoridade, até mesmo a violência. É normal que cada pessoa só fique relativamente tranqüila, diante desses fenômenos, graças a um trabalho interno que pode levar toda a vida. Esse trabalho avançará ainda melhor se for concebido como banal, normal, e não como uma confissão de fraqueza. Ele também supõe competências de auto-análise e de diálogo com seus próximos. (PERRENOUD, 2000, p. 91).

Justamente o que Lopez utilizou com seus aprendizes foi auto-análise e diálogo, conseguindo assim, sanar a violência desencadeada pelo desentendimento dos meninos durante uma discussão.

Percebemos que a maioria das competências sugeridas por Perrenoud (2000) podem ser encontradas na prática do professor Lopez, excluindo-se "o uso de tecnologias", que era inexistente em sua escola e, a que se refere a "administração da própria formação contínua", pois ele estava em seu último ano como professor, prestes a se aposentar. As demais competências são bem presentes. Ainda que, de maneira bem tradicional, ele busca sempre alcançar a aprendizagem efetiva de seus alunos, motivando-os, envolvendo-os nas atividades, favorecendo o trabalho em equipe.

Lopez tem um compromisso com a aprendizagem de seus alunos, mesmo quando leva os maiores para um passeio aproveita os intervalos para ensinar algo aos menores que estão juntos.

O espaço de aprendizagem não é apenas a sala de aula, os alunos de Lopez fazem muitos passeios e tem aulas no jardim da escola, em um campo de trigo, na biblioteca de uma outra escola, brincam na neve, na chuva. Nessa escola tudo é aproveitado em favor da aprendizagem.

O professor visita a casa de seus alunos para conversar com a família, conhecer os pais e saber como eles vivem, assim ele tem uma visão real do problema de cada um, o que talvez o torne mais sensível também em sala de aula, proporcionando uma visão mais adequada do que cada um precisa para poder evoluir em sua aprendizagem. Esta é outra 
competência importante que já citamos, envolver os pais na aprendizagem de seus filhos. Lopez não apenas os faz participar da aprendizagem das crianças como também os chama a refletir sobre os problemas que seus filhos enfrentam.

Quando ele percebe que uma de suas alunas tem uma dificuldade mais intensa em aprender, em relação aos demais colegas, ele se mostra extremamente compreensivo e busca ajudá-la. O professor conversa com a mãe da aluna, está sempre atento na sala de aula e mesmo quando chega o fim do ano letivo, em que ele sabe que a aluna terá que mudar de escola, se coloca a disposição para continuar ajudando-a com os trabalhos da nova escola. Este é um dos momentos mais marcantes e emocionantes do filme.

Sabemos que o ideal é buscar um apoio para trabalhar com crianças que apresentam uma deficiência intelectual, porém conforme propõe Perrenoud (2000), também é possível ao professor oferecer esse apoio.

Do ponto de vista das competências em jogo, percebe-se que os professores deverão, com o tempo, apropriar-se de uma parte dos saberes e do savoirfaire dos professores especializados ou dos professores de apoio, mesmo que nem todos exerçam essa função permanentemente. Isso supõe não só competências mais precisas em didática e em avaliação, mas também capacidades relacionais que permitam enfrentar, sem se desestabilizar, nem desencorajar, resistências, medos, rejeições, mecanismos de defesa, fenômenos de transferência, bloqueios, regressões e todo tipo de mecanismos psíquicos no decorrer dos quais dimensões afetivas, cognitivas e relacionais conjugam-se para impedir que aprendizagens decisivas comecem ou prossigam normalmente. (PERRENOUD, 2000, p. 61).

Por certo o professor Lopez se mostrou muito capaz de lidar com os problemas de seus aprendizes, usando como principal aliada a afetividade e, dessa maneira, conseguiu fazer com que mesmos aqueles com dificuldades de aprendizagem participassem e produzissem durante a aula.

Em outro momento o professor também demonstra sua compaixão com outro aluno que sofre devido ao problema de saúde do pai, o professor conversa com ele enquanto este chora lamentando a grave doença.

É em meio a estas cenas, ora na sala de aula, ora na casa das crianças, ora em outros espaços que acompanhamos o desenvolvimento destas crianças, que durante um ano letivo, aprendem a ler, escrever, raciocinar, e crescem humanamente, tendo como exemplo, o severo porém, amigo sempre presente, professor Lopez.

$\mathrm{Na}$ cena em que se apresenta o final do ano letivo, e também do filme, temos mais um momento intenso, em que os alunos de despedem do professor e o professor se despede da escola, pois após trinta e cinco anos de trabalho ele se aposentou e não voltará mais para lá. Com a imagem da sala de aula vazia e uma bela paisagem de neve caindo na janela a história chega ao fim, deixando os espectadores bastante emocionados. E, deixando sobretudo aos profissionais da educação uma aula de uma prática docente humana, engajada e comprometida com a formação dos cidadãos.

Neste sentido a prática do professor Lopez também combina bem com as competências propostas por Freire (2001) quando este diz que ensinar exige segurança, competência profissional, generosidade, comprometimento, liberdade e autoridade, tomada consciente de decisões, saber escutar, disponibilidade para o diálogo, e, principalmente, querer bem aos educandos. 
Outra qualidade indispensável à autoridade em suas relações com as liberdades é a generosidade. Não há nada que mais inferiorize a tarefa formadora da autoridade do que a mesquinhez com que se comporte.

A arrogância farisaica, malvada, com que julga os outros e a indulgência macia com que se julga ou com que julga os seus. A arrogância que nega a generosidade nega também a humildade, que não é virtude dos que ofendem nem tampouco dos que se regozijam com sua humilhação. O clima de respeito que nasce de relações justas, sérias, humildes, generosas, em que a autoridade docente e as liberdades dos alunos se assumem eticamente, autentica o caráter formador do espaço pedagógico. (FREIRE, 2001, p. 92).

Vemos nesse excerto de Freire (2001) uma definição que muito se adequa ao professor Lopez, sua autoridade é imensamente completada por sua generosidade para com seus aprendizes, eles se respeitam mutuamente, a ligação afetiva entre professor e aprendiz é intensa e ao mesmo tempo não ultrapassa o limite desse respeito, não há humilhações nesta sala de aula, pois sobra ética e esse querer bem por parte do professor.

\section{Considerações finais}

Objetivamos, neste estudo, analisar dois filmes em que se abordam realidades da escola e, utilizando exemplos dessas realidades, tratar das competências dos docentes apresentados em ambos os filmes, apontando aquelas com maior destaque.

Enquanto no primeiro filme abordado, Entre os muros da escola, a ausência de várias competências é marcante, sobretudo, no que se refere ao engajamento do professor François, em relação à ética e à aprendizagem de seus alunos; no segundo filme Ser e Ter o professor Lopez possui na verdade uma única competência de destaque: o amor por sua profissão, o que nos mostra que para se alcançar a maioria das competências propostas pelos teóricos que abordamos, o docente deve em primeiro lugar gostar de sua profissão, gostar de ser professor e passar essa paixão aos seus aprendizes. Assim, todas as demais competências serão provavelmente adquiridas com mais facilidade, naturalmente, em conseqüência dessa paixão; pois quem ama o que faz com certeza se compromete e procura fazer da melhor maneira possível o seu ofício.

É claro que tais competências não surgem do nada, de uma hora para outra, conforme Alessandrini (2000 apud PERRENOUD, 2002, p. 166), elas são formadas passo a passo, "segundo um processo de construção contínuo e esse processo ocorre a partir de um diálogo interior, representado pelas relações intrapessoais, assim como pelas relações interpessoais, as quais implicam inserção e responsabilidade social". E ainda após conquistar tais competências o docente deve sempre procurar reavaliá-las, pois assim ele conseguirá também semear novas competências a serem construídas pelos aprendizes com os quais trabalha, e isso expressa seu propósito em reconhecer o potencial criativo e transformador que cada ser humano possui, independentemente de sua problemática ou forma de ser. É preciso compreender as demandas de nossos alunos e trabalharmos no sentido de atendê-las, de forma a desenvolver nossas competências e possibilitar seu desenvolvimento, segundo um alinhamento ético, em uma cultura de paz permeada por valores humanos.

A escolha de filmes para refletir sobre a prática docente foi devido sobretudo à neutralidade do corpus. Se trabalhássemos com aulas reais de professores próximos e conhecidos, isso poderia causar certo constrangimento, então ao adotar filmes estrangeiros temos um distanciamento que nos permite uma maior liberdade na análise e reflexão dos fatos. E, estes dois filmes escolhidos têm servido também como exercício reflexivo em muitas reuniões pedagógicas de escolas brasileiras. 
Exercícios de reflexão dessa natureza, sobre a prática docente, são uma boa maneira de alcançar metas ou mesmo buscar melhorar suas competências, pode se começar assim com filmes, para em seguida o professor avaliar sua própria prática.

Acerca do ato reflexivo Schön (2000) afirma:

[...] é possível através da observação e da reflexão sobre nossas ações, fazermos uma descrição do saber tácito que está implícito nelas. Nossas descrições serão de diferentes tipos, dependendo de nossos propósitos e das linguagens disponíveis para essas descrições. Podemos fazer referência, por exemplo, às seqüências de operações e procedimentos que executamos; aos indícios que observamos e às regras que seguimos; ou os valores, às estratégias e aos pressupostos que formam nossas "teorias da ação". (SHÖN, 2000, p. 31).

Percebemos que esta concepção de uma reflexão sobre a prática nos leva a uma série de transformações em nosso perfil enquanto profissionais em sala de aula, cuja reflexão conduz a um pensamento crítico, permitindo-nos a identificar a atual situação de nossa prática docente, assim, como identificar o que está sendo construído por nossos alunos durante este processo de ensino. Tal ato reflexivo também gera uma consequente mudança de atitude profissional.

A construção de uma prática reflexiva permite a reformulação de conceitos, assim como uma participação mais ativa e contestadora do docente sobre sua própria ação, tirando este da posição de mero transmissor de conteúdos. A partir deste exercício de reflexão o professor tem condições de desenvolver uma prática mais significativa, mais coerente não apenas com seu perfil de educador mas também com a realidade de seus aprendizes.

Sabemos que atualmente são raras as instituições que oferecem condições para seus professores realizarem uma prática de qualidade, pois isto requer não apenas dedicação como tempo e envolvimento de todos os participantes, não apenas do professor em sala de aula mas de seus alunos e todos os gestores de sua instituição.

Esse exercício de uma reflexão crítica fornece ao professor a possibilidade de desenvolver competências necessárias para seu ofício, uma vez que durante este processo ele pode observar, refletir, indagar, confrontar conceitos e agir de forma inovadora. Agindo assim o docente tem condições de adquirir novos conhecimentos além de atualizar a própria prática, construindo situações que proporcionem um resultado mais satisfatório do seu trabalho.

[...] a noção de professor reflexivo baseia-se na consciência da capacidade de pensamento e reflexão que caracteriza o ser humano criativo e não como mero reprodutor de idéias e práticas que lhe são exteriores. É central, nesta conceptualização, a noção do profissional como uma pessoa que, nas situações profissionais, tantas vezes incertas e imprevistas, actua de forma inteligente e flexível, situada e reactiva. (ALARCÃO, 2003, p. 41).

Certamente é este o perfil do bom profissional e este deve ver esta prática como um suporte à sua atuação, algo que lhe possibilite mudar, unindo o seu conhecimento teórico à sua prática pedagógica, não pode considerá-lo como uma mera avaliação para ser relatada ao seu coordenador, e sim como algo que realmente o faça conceber melhoras em suas aulas, fornecendo novos aparatos e novas visões à sua atividade docente.

O docente que realiza com frequência o exercício de se reavaliar, de refletir sobre suas ações em sala de aula, participa de uma formação contínua, seja dentro da instituição de ensino ou fora dela, busca aperfeiçoar-se em cursos de especialização ou de pós-graduação, é 
engajado com o ofício que escolheu e alcançará sem dúvida as competências necessárias para exercer eficazmente o seu trabalho.

\section{Referências}

ALARCÃO, I. Professores reflexivos em uma escola reflexiva. São Paulo: Cortez, 2003.

FREIRE, P. Pedagogia da Autonomia. Saberes necessários à prática educativa. 18.ed. Rio de Janeiro: Paz e Terra, 2001.

MACEDO, L. Competências na educação. 2008 Disponível em: http://www.odetemf.org.br/autores/COPETENCIAS\%20NA\%20EDUCA\%C7\%C3O.pdf

MORIN, E. Os sete saberes necessários à educação do futuro. Tradução de Catarina Eleonora F. da Silva e Jeanne Sawaya. São Paulo: Cortez: UNESCO, 2003.

PERRENOUD, P. 10 novas competências para ensinar. Porto Alegre: Artmed, 2000.

As competências para ensinar no século XXI: a formação dos professores e o desafio da avaliação. Porto Alegre: Artmed, 2002.

SCHÖN, D. Educando o profissional reflexivo: um novo design para o ensino e a aprendizagem. Porto Alegre: ARTMED, 2000.

TARDIF, M. Saberes docentes e formação profissional. Petrópolis: Vozes, 2002.

\section{Filmes:}

ENTRE os muros da escola. Direção: Laurent Cantet, Produtora: Imovision, 2008. 1 DVD (128 min), Título original: Entre les murs.

SER e Ter. Direção: Nicolas Philibert, Produtora: Video Filmes, 2002. 1 DVD (104 min), Título original: Être et Avoir.

Recebido em: junho de 2013.

Aprovado em: agosto de 2013. 